\title{
BIOLOGICAL MANIPULATION OF MIGRATION RATE: THE USE OF ADVANCED PHOTOPERIOD TO ACCELERATE SMOLTIFICATION IN YEARLING CHINOOK SALMON
}

\author{
Annual Report 1988
}

\author{
by: \\ Albert E. Giorgi \\ William D. Muir \\ Waldo S. Zaugg \\ and \\ Scott McCutcheon
}

Coastal Zone and Estuarine Studies Division

Northwest Fisheries Center

National Marine Fisheries Service

National Oceanic and Atmospheric Administration

\author{
prepared for: \\ U.S. Department of Energy \\ Bonneville Power Administration \\ Division of Fish and Wildlife \\ P.O. Box 3621 \\ Portland,OR 97208-3621
}

Contract No. DE-AI79-88-BP50301

Project No.88-141

February 1990 


\begin{abstract}
Research was conducted to assess the feasibility of biologically manipulating physiological development and migratory behavior of yearling spring chinook salmon, Oncorhynchus tshawytscha. At Dworshak National Fish Hatchery a treatment group was exposed to a 3-month advanced photoperiod cycle for 14 weeks preceding release. Physiological development and migratory performance of this group was compared to a control group. Changes in physiological indices indicated that exposing fish to an advanced photoperiod treatment increased the rate of smolt development. Photoperiod treatment also altered passage patterns and timing at Lower Granite Dam.
\end{abstract}





\section{CONTENTS}

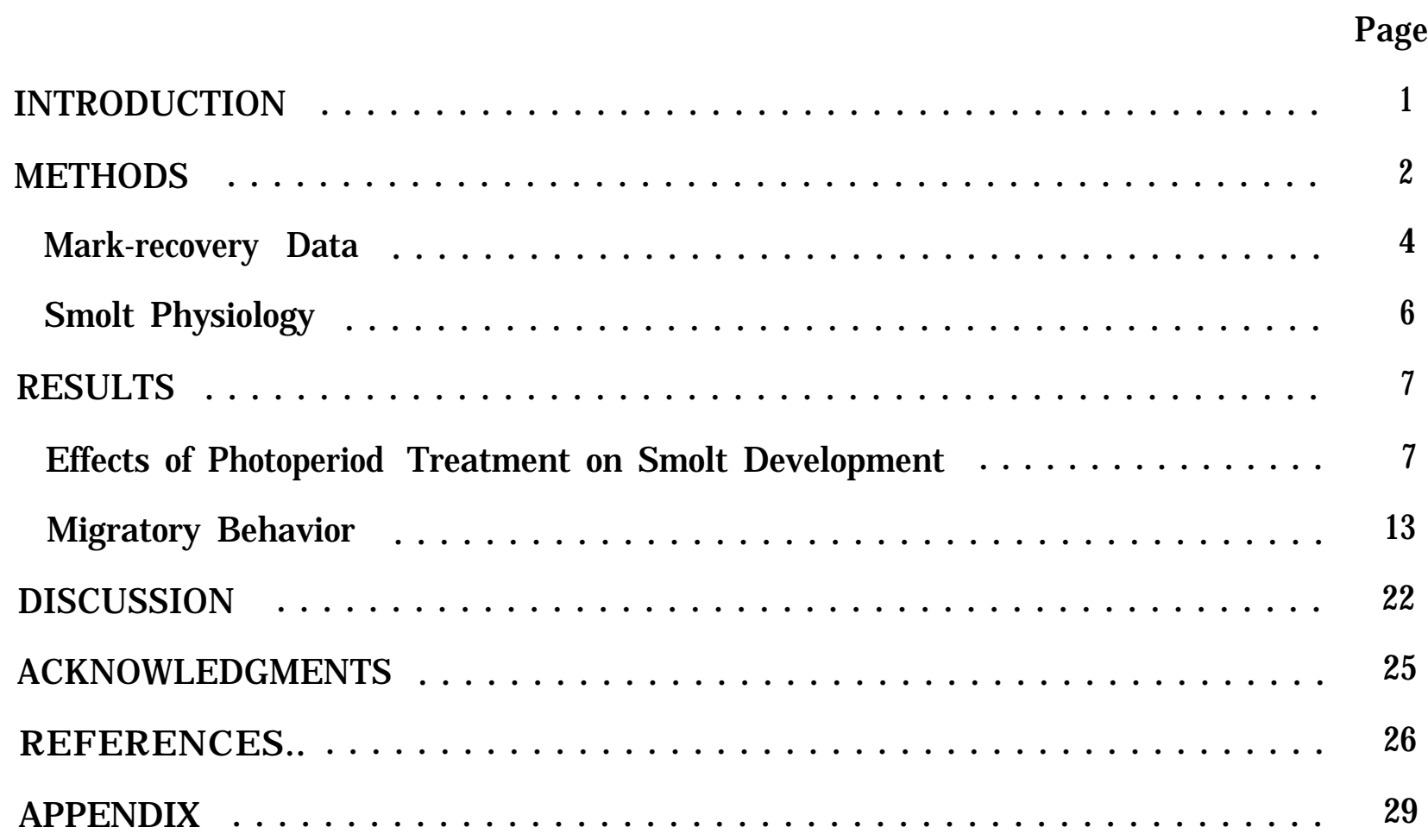




\section{INTRODUCTION}

Hydroelectric development on the Columbia and Snake Rivers has created conditions which adversely affect juvenile salmonids as they migrate seaward (Ebel 1977; Raymond 1979). The dams cause mortality directly by killing fish passing through turbines and spillways. Indirectly, the impoundments created by dams also affect smolt survival. They retard natural spring flow patterns resulting in delayed migrations and accompanying protracted exposure of smolts to predators (Poe and Rieman 1988). In drought years, smolts run the additional risk of mortality due to degrading environmental conditions, particularly in the form of increasing water temperature (Zaugg and Wagner 1973).

The relationship between increasing river flow volumes and faster inriver migration has been demonstrated for both yearling chinook salmon, Oncorhynchus

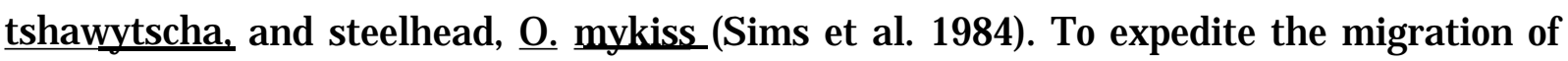
smolts through the river system, particularly in low-flow years, the Northwest Power Planning Council established a Water Budget Program (NWPPC 1987). This program calls for strategic releases of water from storage reservoirs to flush smolts through the system. However, juvenile salmonids may not fully respond to such measures if they are not physiologically prepared to migrate. Zaugg (1981) presented evidence that subyearling chinook salmon migrated at different rates depending on their level of physiological development within the transformation from parr to smolt. Juveniles in the more advanced stages of smolt development exhibited the highest migration rates inriver.

It has been demonstrated that smolt development of hatchery stocks of salmonids may be accelerated by altering environmental conditions, especially temperature and photoperiod (see reviews by Poston 1978; Wedemeyer et al. 1980). Furthermore, there is evidence that changes in migratory behavior of steelhead accompany such 
physiological changes (Zaugg and Wagner 1973; Wagner 1974). However these data are based largely on laboratory observations of small numbers of animals or limited numbers of marked fish migrating inriver. Depleted stocks of spring chinook salmon from the upper Snake River drainage have been the subject of much research in recent years (Raymond 1988). As a consequence, many management activities are directed toward them. This race in particular, stands to benefit the most from expeditious inriver migration.

The purpose of this research was to determine the feasibility of biologically manipulating physiological development and migratory behavior of yearling spring chinook salmon. Our strategy was to accelerate smolt development in a hatchery population by subjecting a treatment group to an advanced photoperiod cycle and compare their inriver migratory behavior to a corresponding control group.

\section{METHODS}

The research was conducted using yearling chinook salmon at Dworshak National Fish Hatchery (NFH) on the Clearwater River near Orofino, Idaho (Fig. 1). Starting on 21 December 1987, a treatment group was exposed to a photoperiod cycle advanced 14 weeks beyond the winter equinox. This group was subjected to the treatment for 100 days and released from the hatchery on 30 March 1988. A corresponding control group was exposed only to ambient light conditions during the same period.

Fish within each group were either freeze branded (Mighell 1969) or implanted with passive integrated transponder (PIT) tags (Prentice et al. in press). PIT tags were used to evaluate migrational characteristics while freeze brands were used primarily to recover fish downstream for further physiological examination. Marking was conducted from 15 to 17 December 1987. Two thousand forty fish were PIT tagged and 30,520 fish were branded in the treatment group, and 2,052 were tagged and 30,655 branded in the control group (Table 1). Experimental fish were held in two separate adjacent 
Table 1.--Marking summary for spring chinook salmon from Dworshak National Fish Hatchery photoperiod study. Fish were marked on 15-17 December 1987.

Treatment and control fish were held in separate raceways. PIT-tagged fish in each raceway were reared with approximately 76,000 unmarked fish.

\begin{tabular}{lccccc}
\hline \multirow{2}{*}{$\begin{array}{c}\text { Experimental } \\
\text { condition }\end{array}$} & \multicolumn{2}{c}{ Number marked } & & \multicolumn{2}{c}{ Number released } \\
\cline { 2 - 5 } & PIT tags & Brands & & PIT tags & Brands \\
\hline Treatment & 2,040 & 30,520 & 1,964 & 29,372 \\
Control & 2,052 & 30,655 & 2,028 & 29,096 \\
\hline
\end{tabular}

adjusted for mortality, brand legibility, and tag loss. 
raceways for the duration of the experiment. Each raceway was 24.4-m long by 2.4-m wide, and water depth was $0.6 \mathrm{~m}$. A partition 1.0-m high ran the length of each raceway, splitting each raceway in half. Sidewalls projected $3.0 \mathrm{~m}$ above the water surface. Four light fixtures were suspended from walls of the treatment group raceway $1.8 \mathrm{~m}$ above the surface of the water. This arrangement shielded the control raceway from incidental light. Each fixture was fitted with a 400-watt metal halide bulb. Light operation was controlled by a timing device which was reset every 10 days to maintain the advanced cycle. Light intensity in the raceways was measured with an integrating photometer (Li-Cov Inc., Model LI-188B). ${ }^{1}$ At night surface light intensity in the treatment pond ranged from $36.00 \mu \mathrm{E} \mathrm{s} \mathbf{s}^{-1} \cdot \mathrm{m}^{-2}$ directly beneath the lights to $0.20 \mu \mathrm{E}$ $\mathbf{s}^{-1} \cdot \mathbf{m}^{-2}$ in the darker areas of the pond. At night light intensity in the control pond (from ambient and hatchery security lights) ranged from 0.001 to $0.002 \mu \mathrm{E} \mathrm{s}^{-1} \cdot \mathrm{m}^{-2}$ when measured. All marking and handling occurred prior to initiation of the photoperiod treatment.

Both the treatment and control raceways were maintained on normal hatchery diets and pond maintenance schedules.

Dead fish were regularly removed from the raceways and brands were enumerated. Unbranded fish were stored frozen and at a later date were examined for PIT tags. These data were used to calculate the number of tagged and branded fish released in the treatment and control groups.

\section{Mark-recovery Data}

Subsequent to release from the hatchery, marked individuals were recaptured at three downstream interception sites (Fig. 1). At Lower Granite and McNary Dams branded fish were sampled from the juvenile fish collection systems during routine

'References to trade names do not imply endorsement by the National Marine Fisheries Service, NOAA. 


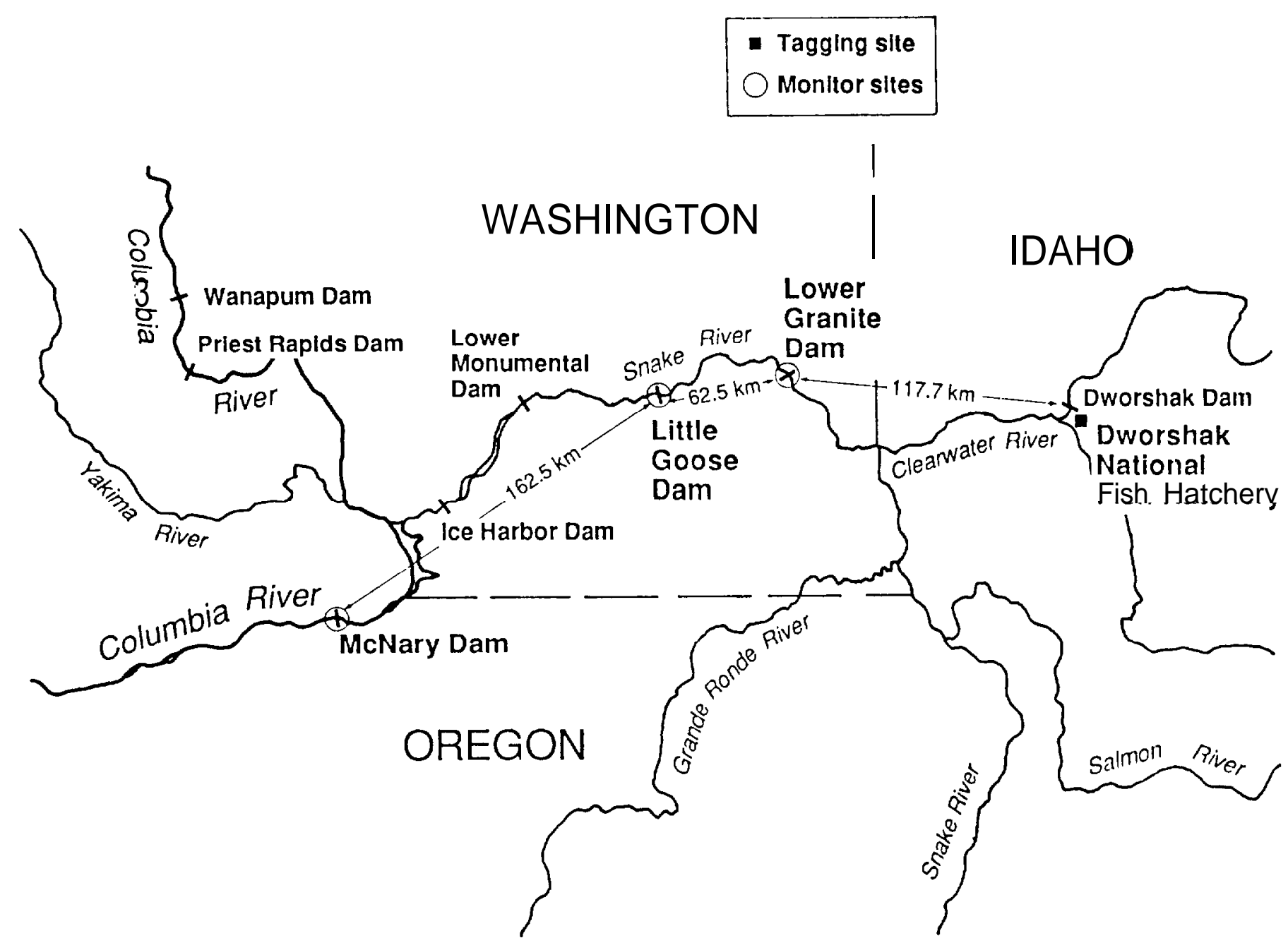

Figure 1.--Location of Dworshak National Fish Hatchery and downstream interception sites in the Snake and Columbia Rivers. River kilometers between sampling sites are indicated. 
smolt monitoring activities (FPC 1989). These fish were later assayed for several physiological indices of smolt development.

Lower Granite, Little Goose, and McNary Dams are equipped with PIT-tag detectors which interrogate $100 \%$ of the juveniles in the juvenile collection systems. The electronic detectors transmit a radio signal which stimulates the tag as a tagged fish passes through the detection tunnel. The tag then transponds its unique code which is in turn "read" by the detector. These data, including the time of detection, are then automatically stored in a computer file. A detailed description of the PIT-tag system is presented in Prentice et al. (in press). PIT-tag data provided detailed information regarding the migration rate of individual fish within the experimental groups as they migrated through the Snake and into the Columbia River.

\section{Smolt Physiology}

To monitor changes in the physiological status of the experimental groups, four indices of smolt development were assayed: gill $\mathrm{Na}^{+}-\mathbf{K}^{+}$ATPase, the thyroid hormones thyroxine $(T$,$) and triiodothyronine \left(\mathrm{T}_{3}\right)$, and a morphometric index. A series of samples was taken at the hatchery from initiation of the treatment until release of the experimental groups. On each occasion a sample of 12 fish was randomly dipnetted from each of the treatment and control groups. Samples were collected monthly from December through February and then weekly until release. Gill filaments from individual fish were trimmed from the gill arch and placed into a $1.5-\mathrm{ml}$ microcentrifuge tube filled with a buffer solution of sucrose, ethylenediamine tetraacetic acid, and imidazole. Samples were stored frozen below $-20^{\circ} \mathrm{C}$ until they were processed. Assays for $\mathrm{Na}^{+}-\mathrm{K}^{+}$ATPase followed procedures described by Zaugg (1982) with minor modifications. Heparinized blood was centrifuged, and the plasma was collected and frozen until assayed for $T_{3}$ and $T_{4}$ hormones. We used assay procedures described by Dickhoff et al. (1978). A morphometric index was calculated on samples of 12 to 
20 fish which were frozen at the time of capture. Later, fish were thawed, pinned on a flat polystyrene surface, and photographed for subsequent digitizing as described by Winans (1984). This morphometric index describes changes in fish shape associated with the physiological process of smoltification (Winans and Nishioka 1987).

Following release from the hatchery, branded fish intercepted at Lower Granite and McNary Dams were also assayed for these indices.

The Mann-Whitney U-test was employed for statistical comparisons of physiological data (Appendix Tables 1-3). Wilcoxon's 2-sample rank test was used for analysis of the morphometric index data. The chi-square test was used to compare recovery proportions. The paired t-test was used to compare travel time data.

\section{RESULTS}

Effects of Photoperiod Treatment on Smolt Development

During the period of hatchery residence, gill $\mathrm{Na}^{+}-\mathrm{K}^{+}$ATPase activity in the control group increased from a mean of $7.0 \mu \mathrm{mol} \mathrm{Pi} \cdot \mathrm{mg} \mathrm{Prot}^{-1} \cdot \mathrm{h}^{-1}$ on 17 December to $13.6 \mu \mathrm{mol}$ Pi.mg Prot ${ }^{-1} \cdot h^{-1}$ on 29 March (one day preceding liberation from the hatchery). Over that same period, enzyme levels in the treatment group increased from a mean of 6.0 to 15.0 units (Fig. 2, Table 2). By 22 March, enzyme levels in the treatment group were significantly higher $(\mathrm{P}<0.01)$ than those observed in the control group (Fig. 2).

One week later (29 March), just prior to release, the treatment fish continued to exhibit enzyme levels higher (not significant) than the controls.

Subsequent to release from the hatchery on 30 March, a sample of freeze-branded fish were collected at the first downstream interception site, Lower Granite Dam, on 18 April. Both groups exhibited enzyme levels which were significantly higher $(\mathrm{P}<0.001)$ than observed at release, with means of 30.4 and 24.8 units (medians were 30.5 and 24.4) for the treatment and control groups, respectively (Fig. 2). Furthermore, the enzyme levels in the treatment group were significantly higher $(\mathrm{P}<0.01)$ than the 


\section{GILL ATPase Dworshak}

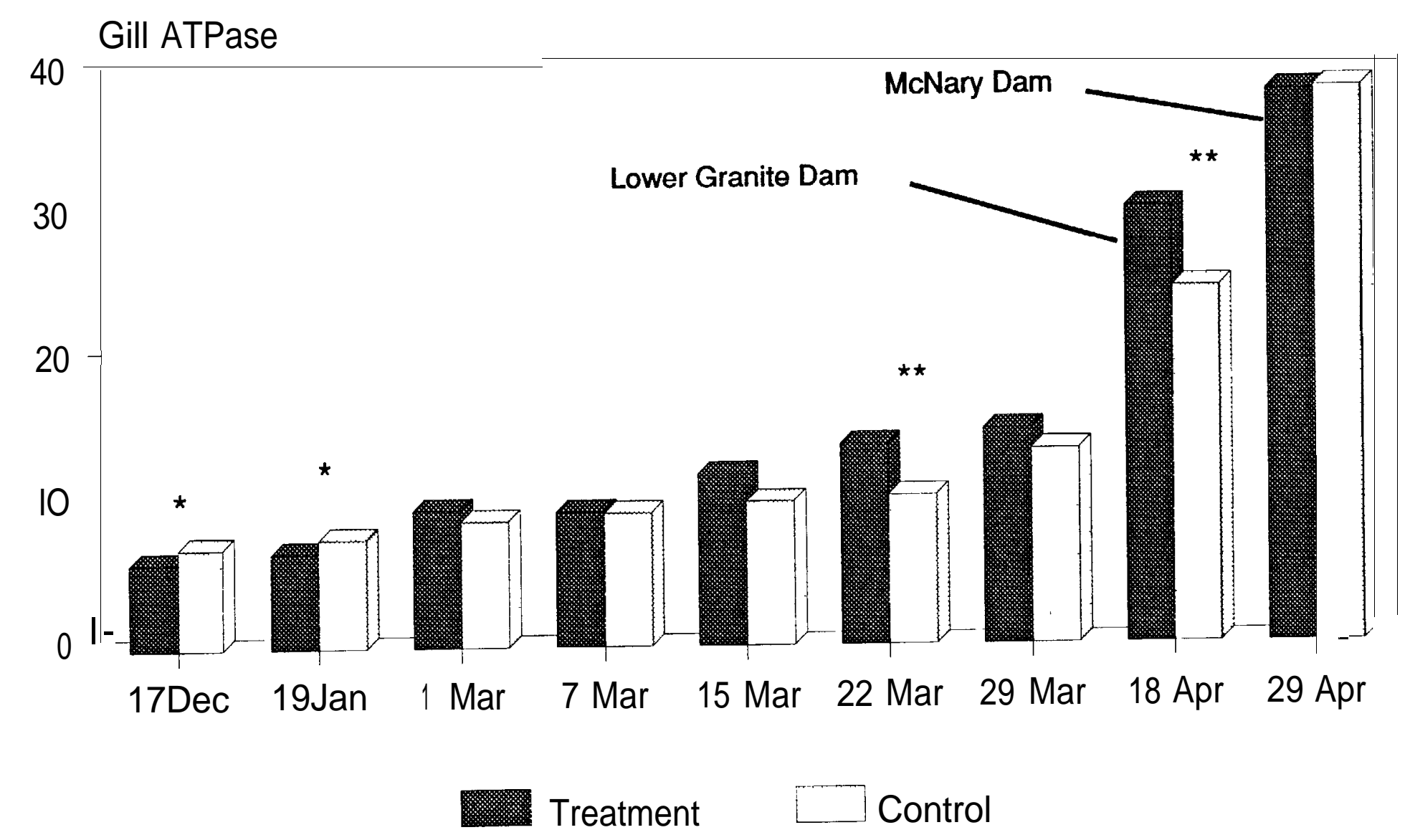

Figure 2.--Mean gill $\mathrm{Na}^{+}-\mathrm{K}^{+}$ATPase activities ( $\mu \mathrm{mol}$ Pi.mg Prot ${ }^{-1} \cdot \mathrm{h}^{-1}$ ) from branded spring chinook salmon photoperiod treatment and control groups collected at Dworshak National Fish Hatchery and downstream recovery sites $(\mathrm{n}=11$ to 12$) . *=0.01<\mathrm{P}<0.05, * *=0.001<\mathrm{P}<0.01$. 
Table 2.--Physiological data from spring chinook salmon from Dworshak photoperiod experiment. Values are means of 8 to 12 fish samples with standard deviations in parentheses. $\mathrm{T}=$ test; $\mathrm{C}=$ control. Units for $\mathrm{Na}^{+}-\mathrm{K}^{+}$ATPase and thyroid hormones are $\mu \mathrm{mol} \mathrm{Pi} \cdot \mathrm{mg} \operatorname{Prot}^{-1} \cdot \mathrm{h}^{-1}$ and $\mathrm{ng} \mathrm{ml} \mathbf{l}^{-1}$, respectively.

\begin{tabular}{|c|c|c|c|c|c|}
\hline $\begin{array}{l}\text { Sample } \\
\text { site }\end{array}$ & Date & $\begin{array}{l}\text { Test } \\
\text { cond. }\end{array}$ & $\begin{array}{l}\mathrm{Na}^{+}-\mathbf{K}^{+} \\
\text {ATPase }\end{array}$ & $\mathrm{T}_{3}$ & $\mathrm{~T}_{4}$ \\
\hline \multirow{8}{*}{$\begin{array}{l}\text { Dworshak } \\
\text { National } \\
\text { Fish } \\
\text { Hatchery }\end{array}$} & 17 Dee & $\begin{array}{l}\mathrm{T} \\
\mathrm{C}\end{array}$ & $\begin{array}{l}6.0(1.1) \\
7.0(1.1)\end{array}$ & $\begin{array}{ll}1.0 & (0.2) \\
1.2 & (0.4)\end{array}$ & $\begin{array}{ll}5.4 & (0.5) \\
5.4 & (0.9)\end{array}$ \\
\hline & 19 Jan & $\begin{array}{l}\mathrm{T} \\
\mathrm{C}\end{array}$ & $\begin{array}{ll}6.7 & (0.9) \\
7.6 & (1.0)\end{array}$ & $\begin{array}{ll}1.9 & (0.7) \\
1.5 & (1.0)\end{array}$ & $\begin{array}{ll}6.3 & (1.3) \\
5.7 & (1.2)\end{array}$ \\
\hline & 22 Feb & $\begin{array}{l}\mathrm{T} \\
\mathrm{C}\end{array}$ & $\begin{array}{ll}- & - \\
- & -\end{array}$ & $\begin{array}{ll}2.9 & (0.8) \\
2.6 & (1.0)\end{array}$ & $\begin{array}{l}8.0(1.5) \\
7.4(1.2)\end{array}$ \\
\hline & $1 \mathrm{Mar}$ & $\begin{array}{l}\mathrm{T} \\
\mathrm{C}\end{array}$ & $\begin{array}{ll}9.6 & (2.2) \\
8.8 & (1.3)\end{array}$ & $\begin{array}{ll}2.9 & (1.3) \\
2.7 & (0.9)\end{array}$ & $\begin{array}{ll}6.7 & (1.6) \\
7.3 & (1.3)\end{array}$ \\
\hline & 7 Mar & $\begin{array}{l}\mathrm{T} \\
\mathrm{C}\end{array}$ & $\begin{array}{ll}9.4 & (1.3) \\
9.3 & (1.5)\end{array}$ & $\begin{array}{ll}2.4 & (1.1) \\
2.8 & (1.9)\end{array}$ & $\begin{array}{ll}5.6 & (2.5) \\
5.6 & (2.6)\end{array}$ \\
\hline & 15 Mar & $\begin{array}{l}\mathrm{T} \\
\mathrm{C}\end{array}$ & $\begin{array}{l}12.0(2.6) \\
10.0(2.0)\end{array}$ & $\begin{array}{l}2.6(1.8) \\
2.9(1.9)\end{array}$ & $\begin{array}{l}7.0(3.4) \\
6.0(2.5)\end{array}$ \\
\hline & $22 \mathrm{Mar}$ & $\begin{array}{l}\mathrm{T} \\
\mathrm{C}\end{array}$ & $\begin{array}{l}14.0(3.3) \\
10.4(1.1)\end{array}$ & $\begin{array}{ll}1.4 & (1.1) \\
3.6 & (2.0)\end{array}$ & $\begin{array}{ll}5.2 & (1.7) \\
7.9 & (3.4)\end{array}$ \\
\hline & $29 \mathrm{Mar}$ & $\begin{array}{l}\mathrm{T} \\
\mathrm{C}\end{array}$ & $\begin{array}{ll}15.0 & (2.5) \\
13.6 & (2.3)\end{array}$ & $\begin{array}{ll}0.6 & (0.6) \\
1.0 & (0.5)\end{array}$ & $\begin{array}{l}3.5(1.6) \\
4.6(1.2)\end{array}$ \\
\hline $\begin{array}{l}\text { Lower } \\
\text { Granite } \\
\text { Dam }\end{array}$ & $18 \mathrm{Apr}$ & $\begin{array}{l}\mathrm{T} \\
\mathrm{C}\end{array}$ & $\begin{array}{ll}30.4 & (4.8) \\
24.8 & (4.2)\end{array}$ & $\begin{array}{ll}1.9 & (1.2) \\
2.1 & (0.9)\end{array}$ & $\begin{array}{ll}5.9 & (2.1) \\
8.0 & (2.6)\end{array}$ \\
\hline McNary Dam & 29 Apr & $\begin{array}{l}\mathrm{T} \\
\mathrm{C}\end{array}$ & $\begin{array}{ll}38.5 & (8.3) \\
38.7 & (8.9)\end{array}$ & $\begin{array}{ll}2.0 & (0.5) \\
2.7 & (1.3)\end{array}$ & $\begin{array}{ll}5.3 & (2.6) \\
6.1 & (3.9)\end{array}$ \\
\hline
\end{tabular}


control group. On 29 April at McNary Dam, gill ATPase levels were nearly the same in both groups. The mean values for treatment and control groups were 38.5 and 38.7 units (medians were 37.9 and 38.2), respectively.

Thyroxine $\left(\mathrm{T}_{4}\right)$ levels at the hatchery in both the treatment and control groups were generally low throughout the study (Fig. 3). However, treatment and control groups exhibited different patterns of hormone development during the experiment. $\mathrm{T}_{4}$ levels in the treatment group peaked at $8.0 \mathrm{ng} \cdot \mathrm{ml}^{-1}$ one month (22 February) earlier than the control (Fig. 3). The control group attained nearly the same maximum concentration of $7.9 \mathrm{ng} \cdot \mathrm{ml}^{-1}$ on $22 \mathrm{March}$.

Upon recapture downstream at Lower Granite Dam on 18 April, both the control and test groups had significantly higher $\mathrm{T}_{4}$ levels than at release $(\mathrm{P}<0.001$ and $\mathrm{P}<0.01$, respectively). The test group increased to $5.9 \mathrm{ng} \cdot \mathrm{ml}^{-1}$, while the control group increased to $8.0 \mathrm{ng} \cdot \mathrm{ml}^{-1}$, which was significantly higher $(\mathrm{P}<0.05)$ than the test group. When sampled at McNary Dam on 29 April, the control group continued to have higher $\mathrm{T}_{4}$ activity, but not significantly so (Table 2 ).

Triiodothyronine $\left(\mathbf{T}_{\mathbf{3}}\right)$ levels in the treatment group peaked on 22 February and $1 \mathrm{March}$ at $2.9 \mathrm{ng} \cdot \mathrm{ml}^{-1}$, then declined to their lowest level at $0.6 \mathrm{ng} \cdot \mathrm{ml}^{-1}$ at the time of release on 29 March (Fig. 4 and Table 2). The control group's T, level did not peak until 22 March, approximately one month later than the treatment group. This level $\left(3.6 \mathbf{~ n g} \cdot \mathbf{m l}^{-\mathbf{1}}\right)$ was significantly higher $(\mathbf{P}<0.001)$ than the treatment groups level (1.4 $\mathbf{n g} \cdot \mathbf{m l}^{-1}$ ) on this date. The control group's $\mathbf{T}_{\mathbf{3}}$ level then declined significantly to $1.0 \mathbf{n g} \mathrm{ml}^{-1}(\mathrm{P}<0.001)$ at the time of release on $29 \mathrm{March}$, but was still higher than $\mathrm{T}_{\mathbf{3}}$ levels in the test group at release.

Upon recapture at Lower Granite Dam on 18 April, both groups had similar $\mathbf{T}_{3}$ levels which were elevated significantly $(\mathrm{P}<0.01)$ compared to their levels at release; $\mathbf{T}_{\mathbf{a}}$ continued to increase when captured downstream on 29 April at McNary Dam (Fig. 4 and Table 2). 


\section{Thyroxine Dworshak}

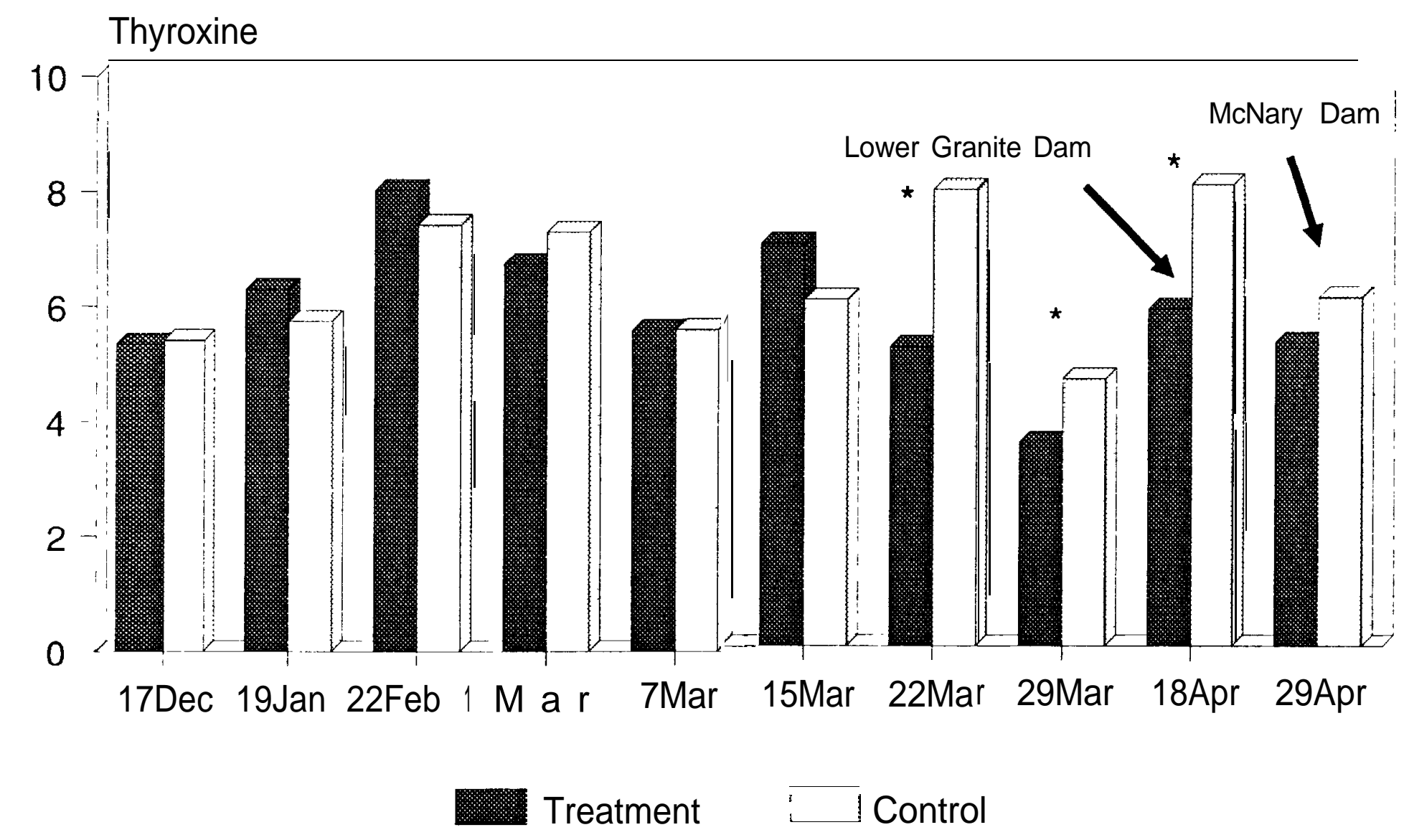

Figure 3.--Mean thyroxine $\left(\mathrm{T}_{4}\right)$ levels $\left(\mathbf{n g} \cdot \mathrm{ml}^{-\mathbf{1}}\right)$ from branded spring chinook salmon photoperiod treatment and control groups collected at Dworshak National Fish Hatchery and downstream recovery sites $(\mathrm{n}=11$ to 12$)$. 


\section{TRHODOTHYRONINE Dworshak}

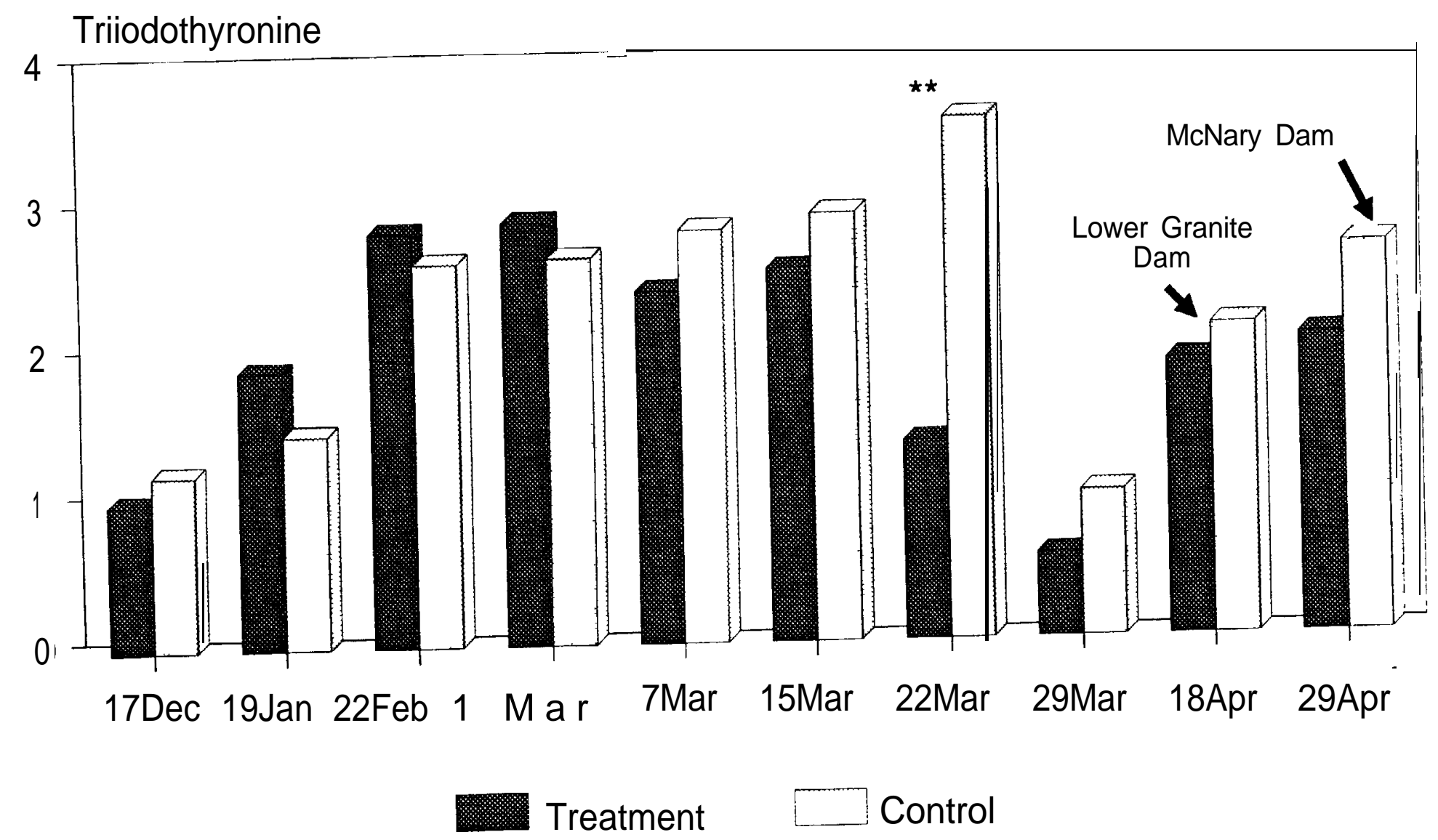

Figure 4.---Mean triiodothyronine $\left(\mathbf{T}_{3}\right)$ levels $\left(\mathrm{ngml}^{-1}\right)$ from branded spring chinook salmon photoperiod treatment and control groups collected at Dworshak National Fish Hatchery and downstream recovery sites ( $\mathrm{n}=8$ to 12 ). $=0.001<\mathrm{P}<0.01$. 
The advanced photoperiod cycle caused changes in the morphometric index. This difference was reflected in Principal Component II (PC II) which is interpreted as differential growth of the caudal peduncle (Winans and Nishioka 1987). Treatment fish exhibited responses early. By 19 January, treatment and control groups were significantly different with mean PC II values of 0.23 and 1.12, respectively. This trend continued until release (Fig. 5). At release (29 March), treatment fish again exhibited PC II values which indicated accelerated development relative to controls. Treatment and control groups were significantly different $(\mathrm{P}<0.0 \mathrm{l})$, with mean values of -0.70 and -0.01 , respectively. Upon recapture at Lower Granite and McNary Dams, PC II values for the control fish were similar to values for the treatment fish and were not significantly different (Table 3 and Fig. 5).

\section{Migratory Behavior}

A total of $471(24.0 \%), 239(12.2 \%)$, and $180(9.2 \%)$ of the 1964 PIT-tagged fish released in the treatment group were detected at Lower Granite, Little Goose, and McNary Dams, respectively (Table 4). At those same dams, 476 (23.5\%), 243 (12.0\%), and $180(8.9 \%)$ of the 2,028 PIT-tagged control fish were detected. At all three collector dams the recovery proportion of the treatment group was slightly higher than the control group, but not significantly so.

Spring chinook salmon exposed to the advanced photoperiod migrated faster to the first dam than the controls (Table 5). The mean travel time from the hatchery to arrival at Lower Granite Dam was 21.9 days for the treatment fish. Controls were significantly slower $(t=5.03, d f=945, p<0.00001)$, on average requiring 24.3 days to reach the dam. At Little Goose Dam, treatment fish still exhibited significantly faster travel times $(t=3.76, d f=480, p<0.001)$ migrating the full $180.2 \mathrm{~km}$ in an average 29.4 days, while controls averaged 32.0 days. At McNary Dam, the last recovery site, 


\section{MORPHOMETRIC INDEX}

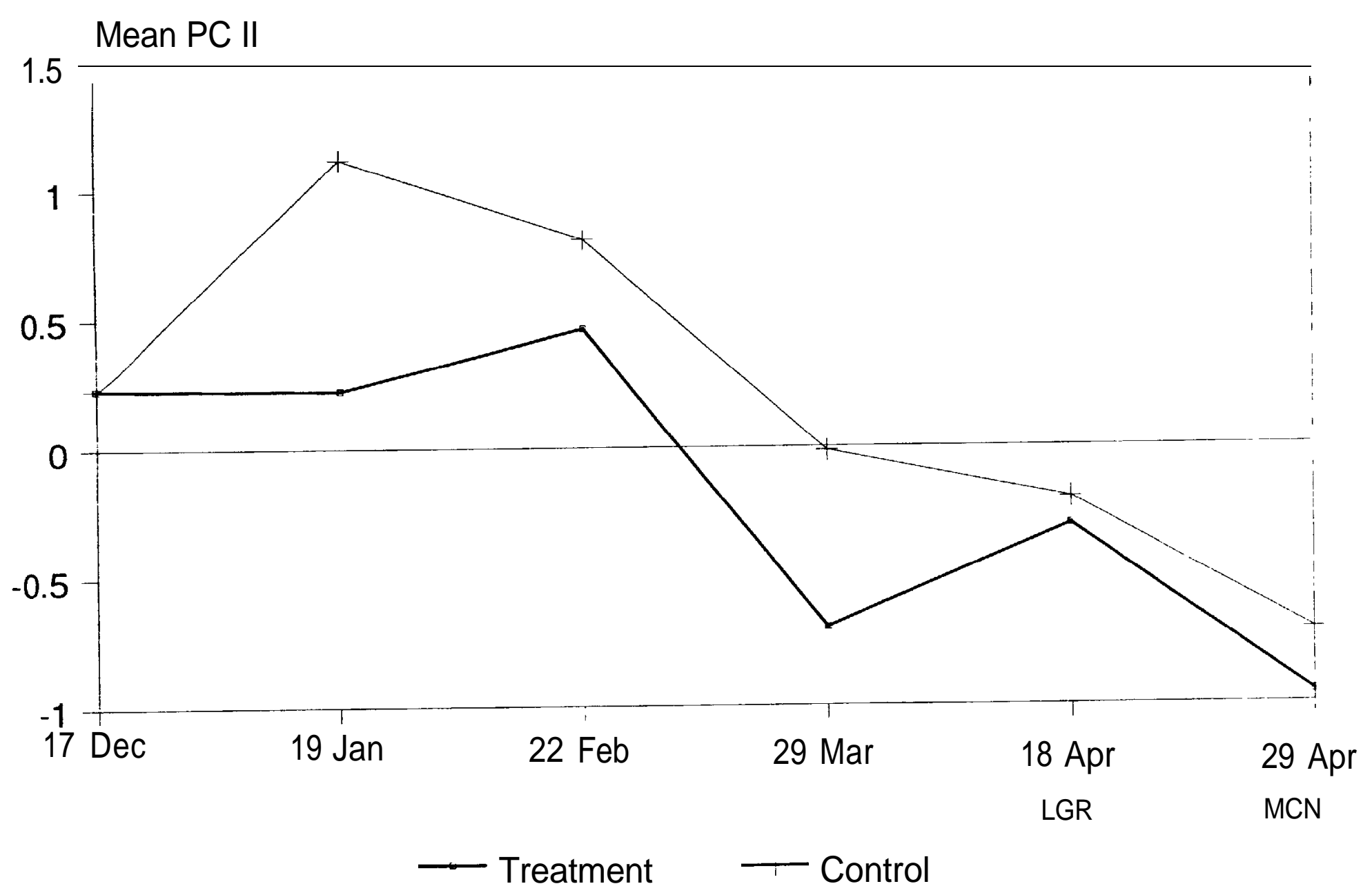

Figure 5--Mean morphometric index of tail shape for branded spring chinook salmon photoperiod treatment and control groups collected at Dworshak National Fish Hatchery and Lower Granite and McNary Dams. Sample sizes were from 12 to 21 fish. 
Table 3.--Morphometric data for changes in Principal Component II (PC II) in spring chinook salmon from Dworshak National Fish Hatchery photoperiod experiment. Probabilities are from Wilcoxon's signed-ranks test (two sample).

\begin{tabular}{|c|c|c|c|c|c|c|}
\hline Date & $\begin{array}{l}\text { Test } \\
\text { condition }\end{array}$ & $\begin{array}{l}\text { Sample } \\
\text { location }\end{array}$ & $\begin{array}{c}\text { Sample } \\
\text { size }\end{array}$ & $\frac{\mathrm{PC}}{\text { Mean }}$ & $\frac{\text { II }}{\text { (S.E.) }}$ & $\mathrm{P}$ \\
\hline 17 Dec & $\begin{array}{l}\text { Treatment } \\
\text { Control }\end{array}$ & Dworshak & 20 & 0.23 & $(0.109)$ & - \\
\hline 19 Jan & $\begin{array}{l}\text { Treatment } \\
\text { Control }\end{array}$ & Dworshak & $\begin{array}{l}12 \\
12\end{array}$ & $\begin{array}{l}0.23 \\
1.12\end{array}$ & $\begin{array}{l}(0.212) \\
(0.145)\end{array}$ & 0.003 \\
\hline 22 Feb & $\begin{array}{l}\text { Treatment } \\
\text { Control }\end{array}$ & Dworshak & $\begin{array}{l}20 \\
21\end{array}$ & $\begin{array}{l}0.46 \\
0.81\end{array}$ & $\begin{array}{l}(0.186) \\
(0.201)\end{array}$ & 0.019 \\
\hline $29 \mathrm{Mar}$ & $\begin{array}{l}\text { Treatment } \\
\text { Control }\end{array}$ & Dworshak & $\begin{array}{l}20 \\
20\end{array}$ & $\begin{array}{l}-0.70 \\
-0.01\end{array}$ & $\begin{array}{l}(0.145) \\
(0.210)\end{array}$ & 0.01 \\
\hline 18 Apr & $\begin{array}{l}\text { Treatment } \\
\text { Control }\end{array}$ & $\begin{array}{l}\text { Lower } \\
\text { Granite Dam }\end{array}$ & $\begin{array}{l}20 \\
20\end{array}$ & $\begin{array}{l}-0.30 \\
-0.20\end{array}$ & $\begin{array}{l}(0.219) \\
(0.155)\end{array}$ & 0.54 \\
\hline 29 Apr & $\begin{array}{l}\text { Treatment } \\
\text { Control }\end{array}$ & McNary Dam & $\begin{array}{l}14 \\
13\end{array}$ & $\begin{array}{l}-0.95 \\
-0.71\end{array}$ & $\begin{array}{l}(0.273) \\
(0.315)\end{array}$ & 0.79 \\
\hline
\end{tabular}


Table 4.--Number and percentage of PIT-tagged spring chinook salmon from Dworshak National Fish Hatchery recovered at Lower Granite, Little Goose, and McNary Dams, 1988.

\begin{tabular}{|c|c|c|c|c|}
\hline \multirow[b]{2}{*}{ Dam } & \multicolumn{2}{|c|}{ Treatment } & \multicolumn{2}{|c|}{ Control } \\
\hline & Number & Percent & Number & Percent \\
\hline Lower Granite Dam & 471 & 24.0 & 476 & 23.5 \\
\hline Little Goose Dam & 239 & 12.2 & 243 & 12.0 \\
\hline McNary Dam & 180 & 9.2 & 180 & 8.9 \\
\hline Total & 890 & 45.3 & 899 & 44.3 \\
\hline
\end{tabular}


Table 5.--Travel time and migration speed of PIT-tagged spring chinook salmon released from Dworshak National Fish Hatchery on 30 March 1988. Recapture sites were at Lower Granite, Little Goose. and McNary Dams.

\begin{tabular}{lllll}
\hline $\begin{array}{l}\text { Recovery } \\
\text { site }\end{array}$ & $\begin{array}{c}\text { Experimental } \\
\text { group }\end{array}$ & $\begin{array}{l}\text { Travel time (days) } \\
\text { Mean (SD) Median }\end{array}$ & $\begin{array}{c}\text { Mean migration speed from } \\
\text { hatchery to recovery site }(\mathrm{km} / \mathrm{d})\end{array}$ \\
\hline $\begin{array}{l}\text { Lower } \\
\text { Granite }\end{array}$ & Treatment & $21.9(6.9)$ & 20.9 & 5.4 \\
Dam & Control & $24.3(8.2)$ & 21.9 & 4.8 \\
Little & & & & \\
Goose & Treatment & $29.4(6.9)$ & 28.4 & 6.1 \\
Dam & Control & $32.0(8.2)$ & 30.9 & 5.6 \\
McNary Dam & & & & \\
& & & & \\
& Treatment & $39.9(5.7)$ & 40.4 & 8.6 \\
& Control & $40.9(6.2)$ & 41.4 & 8.4 \\
\hline
\end{tabular}


controls were still lagging behind, but not significantly so, with mean travel times for treatment and controls at 39.9 and 40.9 days, respectively.

Another indication of the difference in migration rate of the two groups is apparent when the passage data are viewed as percentiles. The tenth percentile of each group arrived at Lower Granite Dam only one day apart (Table 6). The ninetieth percentile for the treatment group arrived 14.2 days later. However, the ninetieth percentile for the controls was not observed until 20.8 days after its tenth percentile (Fig. 6). As the fish move downstream the difference diminishes. By the time they arrived at McNary Dam there was virtually no difference (Table 6).

Both groups increased their migration rate as they moved downstream (Table 5). The average migration speeds from the hatchery to Lower Granite Dam were 5.4 and $4.8 \mathrm{~km} / \mathrm{d}$ for treatment and control, respectively. From the hatchery to Little Goose Dam, the mean speeds were 6.1 and $5.6 \mathrm{~km} / \mathrm{d}$ for the same groups. Over the entire $342.8 \mathrm{~km}$ from the hatchery to McNary Dam, the migration speeds were nearly the same, averaging $8.6 \mathrm{~km} / \mathrm{d}$ for treatment fish and $8.4 \mathrm{~km} / \mathrm{d}$ for controls.

Freeze brand recoveries provided additional migrational timing data to support the PIT-tag data. Median travel times to Lower Granite and Little Goose Dams for the freeze branded treatment and control groups were the same as those found with PIT tags (Table 7). Again, photoperiod treatment fish had a shorter $80 \%$ passage duration at each of the smolt monitoring facilities, although the duration and percentile dates dates were different (Table 7). Brand recovery rates were generally higher than PITtag recovery rates at Lower Granite and McNary Dams (Table 7) based on expanded passage index counts (FPC 1989). Recovery rates for the treatment group at both sites were significantly higher $(\mathrm{P}<0.001)$ than for the controls; however, these recovery rates were based on expanded actual brand recoveries which ar tificially increased sample size used for the analysis. 
Table 6.--Passage dates for percentages of PIT-tagged spring chinook salmon arriving at Lower Granite, Little Goose, and McNary Dams and the time elapsed between the 10th and 90th percentiles following release from Dworshak National Fish Hatchery, 1988.

\begin{tabular}{|c|c|c|c|c|c|}
\hline \multirow{2}{*}{$\begin{array}{l}\text { Recovery } \\
\text { site }\end{array}$} & \multirow{2}{*}{$\begin{array}{l}\text { Experimental } \\
\text { group }\end{array}$} & \multicolumn{3}{|c|}{ Percentile of run } & \multirow{2}{*}{$\begin{array}{l}\text { 10-90\% segment } \\
\text { (days) }\end{array}$} \\
\hline & & $10 \%$ & $50 \%$ & $90 \%$ & \\
\hline $\begin{array}{l}\text { Lower } \\
\text { Granite } \\
\text { Dam }\end{array}$ & $\begin{array}{l}\text { Treatment } \\
\text { Control }\end{array}$ & $\begin{array}{l}4 / 15 \\
4 / 16\end{array}$ & $\begin{array}{l}4 / 19 \\
4 / 20\end{array}$ & $\begin{array}{l}4 / 29 \\
5 / 07\end{array}$ & $\begin{array}{l}14.2 \\
20.8\end{array}$ \\
\hline $\begin{array}{l}\text { Little } \\
\text { Goose } \\
\text { Dam }\end{array}$ & $\begin{array}{l}\text { Treatment } \\
\text { Control }\end{array}$ & $\begin{array}{l}4 / 22 \\
4 / 23\end{array}$ & $\begin{array}{l}4 / 27 \\
4 / 29\end{array}$ & $\begin{array}{l}5 / 07 \\
5 / 11\end{array}$ & $\begin{array}{l}15.7 \\
18.3\end{array}$ \\
\hline McNary Dam & $\begin{array}{l}\text { Treatment } \\
\text { Control }\end{array}$ & $\begin{array}{l}5 / 01 \\
5 / 02\end{array}$ & $\begin{array}{l}5 / 09 \\
5 / 10\end{array}$ & $\begin{array}{l}5 / 16 \\
5 / 17\end{array}$ & $\begin{array}{l}14.6 \\
14.5\end{array}$ \\
\hline
\end{tabular}




\section{0\% PASSAGE DURATION Dworshak Spring Chinook}

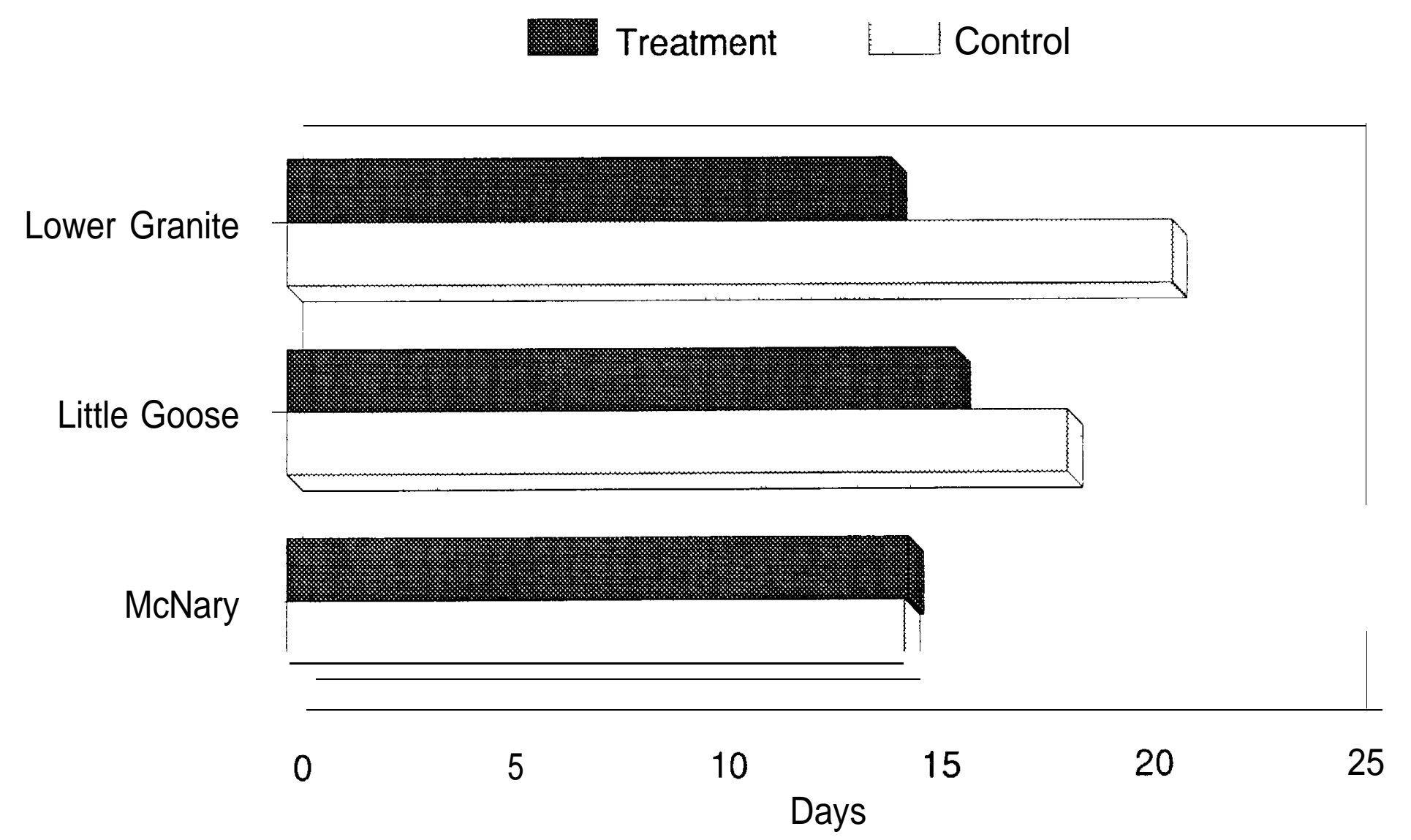

Figure 6.--The mid-80\% passage duration 10-90\% at various dams for photoperiod treatment and control PIT-tagged spring chinook salmon from Dworshak National Fish Hatchery, 1988. 
Table 7.--Summary of passage indices at Lower Granite and Little Goose Dams for freeze branded yearling chinook salmon released from Dworshak NFH photoperiod experiment, 1988. Recovery numbers are FPC "passage index" counts.

\begin{tabular}{|c|c|c|c|c|c|c|c|c|}
\hline $\begin{array}{c}\text { Test } \\
\text { condition }\end{array}$ & $\frac{\text { Reco e }}{\text { Number }}$ & $\frac{r d}{(\%)}$ & $\frac{\text { Perc }}{10 \%}$ & $\frac{\text { ntile }}{50 \%}$ & $\frac{\text { tes }}{90 \%}$ & $\begin{array}{r}10-90 \% \\
\text { (days) }\end{array}$ & $\begin{array}{l}\text { Travel } \\
\text { time } \\
\text { median } \\
\text { (days) }\end{array}$ & $\begin{array}{c}\text { Speed } \\
(\mathrm{km} / \text { day })\end{array}$ \\
\hline \multicolumn{9}{|c|}{ Lower Granite Dam } \\
\hline $\begin{array}{l}\text { Treatment } \\
\text { Control }\end{array}$ & $\begin{array}{l}8,712 \\
7,675\end{array}$ & $\begin{array}{l}(29.7) \\
(26.4)\end{array}$ & $\begin{array}{l}4 / 17 \\
4 / 19\end{array}$ & $\begin{array}{l}4 / 20 \\
4 / 21\end{array}$ & $\begin{array}{l}4 / 25 \\
5 / 04\end{array}$ & $\begin{array}{r}8 \\
15\end{array}$ & $\begin{array}{l}21 \\
22\end{array}$ & $\begin{array}{l}5.6 \\
5.3\end{array}$ \\
\hline $\begin{array}{l}\text { Treatment } \\
\text { Control }\end{array}$ & $\begin{array}{l}3,027 \\
1,886\end{array}$ & $\begin{array}{r}(10.3) \\
(6.5)\end{array}$ & $\begin{array}{l}5 / 01 \\
5 / 02\end{array}$ & $\begin{array}{l}\frac{\mathrm{McN}}{5 / 09} \\
5 / 10\end{array}$ & $\begin{array}{l}\frac{\mathrm{Dan}}{5 / 14} \\
5 / 19\end{array}$ & $\begin{array}{l}13 \\
17\end{array}$ & $\begin{array}{l}40 \\
41\end{array}$ & $\begin{array}{l}8.5 \\
8.4\end{array}$ \\
\hline
\end{tabular}




\section{DISCUSSION}

The smoltification process in salmonids causes morphological, behavioral, and physiological changes which affect, their downstream migration as well as their ability to survive in seawater. In a natural environment this process is regulated primarily by photoperiod and temperature (Folmar and Dickhoff 1980, Wedemeyer et al. 1980). The majority of smolts emigrating from the Snake River are now of hatchery origin and do not become fully smolted while at the hatchery (Muir et al. 1988). They are often exposed to environmental factors which differ from those experienced by natural juveniles. Security lights, constant food supply, and stable water temperatures create unnatural environmental conditions. Furthermore, their release is often dictated by management concerns unrelated to their physiological status (Folmar and Dickhoff 1981). The result is that fish are released which are not physiologically or behaviorally prepared to migrate as evidenced by the lag time between hatchery release and initiation of downstream migration (FPC 1989). In this study we demonstrated that an advanced photoperiod cycle at the hatchery can accelerate the smoltification process in spring chinook salmon and alter migratory patterns as observed at Lower Granite Dam.

The four indices of smolt development we investigated all indicated that exposing spring chinook salmon to a 3-month advanced photoperiod cycle for 14 weeks increased the rate of smolt development. Test fish had significantly higher gill Na+-K+ ATPase levels than controls by $22 \mathrm{March}$, one week prior to release, and these levels were higher at release than had been previously observed at this site. At Lower Granite Dam on 18 April, both the test and control groups had significantly higher Na+-K+ ATPase levels than at release, with the test group being a significantly higher than the control. Na+-K+ ATPase leveis were the same in test and control fish by arrival at McNary Dam, but were higher that had been observed at Lower Granite Dam (Fig. 2)..

Over several years, the measurement of gill $\mathrm{Na}+\mathrm{K}+$ ATPase as an index of smoltification in spring chinook salmon at Dworshak National Fish Hatchery has shown consistent results. We have measured this enzyme at the hatchery for 3 years 
(1986-1988). Enzyme activity has been low and stable at the hatchery from December through release with a two- to three-fold increase when recaptured downstream at Lower Granite Dam (Swan et al. 1987; Muir et al. 1988). Similar results have been found by others (Rondorf et al. 1985, 1988; Zaugg et al. 1985), indicating that the migrational experience, subsequent to release from the hatchery environment, may be necessary for the full development of this enzyme.

There is further evidence that the photoperiod treatment affected the physiological development of spring chinook salmon at the hatchery. Both the thyroid hormones, $\mathbf{T}_{\mathbf{3}}$ and $T_{4}$, exhibited different patterns of expression in the treatment versus control group.

The morphometric index also indicated that treatment fish were farther along in the smoltification process than controls at the time of release. When recaptured at Lower Granite and McNary Dams, treatment fish continued to have lower morphometric values, but the differences were not as great. The Principal Component (PCII) used in these analyses represents changes in the shape of the caudal peduncle. As fish become more smolted they become more streamlined and this can be reflected in the dimension of the peduncle. Changes in tail shape presumable expedites swimming as salmon become a pelagic, migrating fish. Thus, this index (PCII) may be a useful index of smolt development.

Treatment effects were also apparent in downstream migratory behavior. Treatment fish moved downstream faster than the controls as reflected in the mean travel times, as well as the time required for the mid- $80 \%$ of each group to pass Lower Granite Dam, although the differences were small. The effect was most pronounced from the hatchery to Lower Granite and Little Goose Dams (Fig. 6). Treatment fish migrated to these sites significantly faster than the control group. Zaugg and Wagner (1973) and Wagner (1974) found that an advanced photoperiod cycle increased the migration rate in steelhead.

The fact that the mid- $80 \%$ of the treatment group passed Lower Granite Dam in one less week than untreated fish could be of importance in water management. Water 
budget managers request flow augmentation in an effort to flush smolts downstream (NWPPC 1987). Water management activities relative to fish passage are often timed to coincide with the mid- $80 \%$ of the outmigration.

There is another potential benefit associated with photoperiod treatment. By accelerating downstream migration in spring chinook salmon, the peaks of the chinook salmon and steelhead outmigrations would be more temporally separated. This could enable managers to treat the species separately at Lower Granite and Little Goose Darns and implement different passage strategies for each species. For example, under different river flow volumes, it may be desirable to either transport or bypass selected species. Furthermore, even if transportation is utilized for both species, separation by species in the transport vehicles could be beneficial in reducing stress and injury of the chinook salmon.

A higher percentage of treatment group fish than controls were detected at all of the collector dams, although the differences for PIT tag recoveries were not significant (Table 4 and Table 7). If this higher percentage is real, then possible explanations include increased FGE at collector dams or lower reservoir-related mortality by the treatment fish. Giorgi et al. (1988) and Muir et al (1988) presented data which indicated that yearling chinook salmon with elevated gill $\mathrm{Na}^{+}-\mathrm{K}^{+}$ATPase activity were generally more susceptible to guidance by submersible traveling screens at Lower Granite and Little Goose Dams. Since fish exposed to the photoperiod treatment were in the reservoir for a shorter time, they may have also less reservoir-related mortality due to predators. This predation is compounded by the fact that as seasonal water temperatures increase in the spring, predators become more active (Poe and Rieman 1988).

The 14-week exposure to the advanced photoperiod treatment may not have been long enough to elicit a pronounced physiological and behavioral response. Based on preliminary observations, this exposure time was near the minimum we expected would be necessary to elicit a measurable physiological and behavioral response. We would 
have preferred a longer exposure period; however, logistical and funding constraints dictated the length of the exposure period in this pilot study.

Using advanced photoperiod to accelerate smoltification in hatchery smolts is a realistic approach which results in an alteration of certain migratory characteristics in spring chinook salmon. For this study, lights and timers sufficient for treating two raceways containing approximately 80,000 smolts were purchased for under $\$ 1,000$. On a production-wide basis, existing hatchery security lighting systems could be utilized (and expanded if necessary) and regulated with an automatic timer to attain the desired effect at very little cost. This would have a negligible impact on normal hatchery operations.

We are continuing this research at Dworshak National Fish Hatchery during 1989 to refine the photoperiod treatment schedule necessary to elicit the optimum physiological response and downstream migration rate. We are also testing the use of increased temperature alone and increased temperature in combination with advanced photoperiod in accelerating smoltification and downstream migration.

\section{ACKNOWLEDGMENTS}

We express our appreciation to all that assisted us in the conduct of this research. At Dworshak National Fish Hatchery--Wayne Olson, William Miller, Joe Lientz, and their staffs, particularly Travis Coley provided valuable assistance. Dennis Rondorf (U.S. Fish and Wildlife Service) and his staff helped sample fish at the dams for physiological processing. Rodney Duke (Idaho Fish and Game) and Larry Basham (Fish Passage Center) coordinated and conducted the branding of test fish. From the NMFS, Jerrel Harmon collected physiological samples, Brian Beckman conducted enzyme assays, Walton Dickhoff and his staff conducted thyroid hormone assays, and Gary Winans analyzed the morphometric data.

Support for this research came from the region's electrical ratepayers through the Bonneville Power Administration. 


\section{REFERENCES}

Dickhoff, W. W., L. C. Folmar, and A. Gorbman.

1978. Changes in plasma thyroxine during smoltification of coho salmon,

Oncorhvnchus kisutch. Gen. Comp. Endocrinol., 36:229-232.

Ebel, W. J.

1977. Major passage problems. In Schwiebert, E. (ed.), Symposium on Columbia

River salmon and steelhead. Amer. Fish. Soc., Special Publication 10:33-39.

Folmar, L. C., and W. W. Dickhoff.

1980. The parr-smolt transformation (smoltification) and seawater adaptation in salmonids. A review of selected literature. Aquaculture 21:1-37.

Folmar, L. C., and W. W. Dickhoff.

1981. Evaluation of some physiology parameters as predictive indices of smoltification. Aquaculture 23:309-324.

FPC (Fish Passage Center).

1989. 1988 Fish Passage Managers Annual Report: Columbia Basin Fish and Wildlife Authority, Project 87-127, U.S. Department of Energy, Bonneville Power Administration, Portland, Oregon.

Giorgi, A. E., G. A. Swan, W. A. Zaugg, T. C. Coley, and T. Y. Barila.

1988. Susceptibility of chinook salmon smolts to bypass systems at hydroelectric dams. N. Amer. J. Fish. Mgmt. 8:25-29.

Mighell, J. L.

1969, Rapid cold-branding of salmon and trout with liquid nitrogen. J. Fish. Res. Bd. of Can. 26:2765-2769.

Muir, W. D., A. E. Giorgi, W. A. Zaugg, W. W. Dickhoff, and B. R. Beckman. 1988. Behavior and physiology studies in relation to yearling chinook salmon guidance at Lower Granite and Little Goose Dams, 1987. Report to U.S. Army Corps of Engineers, Contract DACW68-84-H-0034, 47 p. Available from Northwest Fisheries Center, 2725 Montlake Blvd. E., Seattle, WA 98112-2097.

NWPPC (Northwest Power Planning Council).

1987. Columbia River Basin fish and wildlife program. Northwest Power Planning Council, Portland, Oregon.

Poe, T. P., and B. E. Rieman (editors).

1988. Predation by resident fish on juvenile salmonids in John Day Reservoir, 1983-1986. Final report to BPA, Portland, Oregon. 377 p.

Poston, H. A.

1978. Neuroendocrine mediation of photoperiod and other environmental influences of physiological responses in salmonids: a review. U.S. Fish and Wildlife Serv., Technical Paper 96:1-14. 
Prentice, E. F., T. A. Flagg, and C. S. McCutcheon.

In press. A passive integrated transponder tag for fish. American Fisheries Society, International Symposium and Educational Workshop on Fish Marking Techniques.

Raymond, H. L.

1979. Effects of dams and impoundments on migrations of juvenile chinook salmon and steelhead from the Snake River, 1966 to 1975. Trans. Amer. Fish. Soc. 108:505-529.

Raymond, H. L.

1988. Effects of hydroelectric development and fisheries enhancement on spring and summer chinook and steelhead in the Columbia River Basin. N. Amer. J. Fish. Mgmt. 8:1-24.

Rondorf, D. W., J. W. Beeman, M. E. Free, and D. E. Liljegren.

1988. Correlation of Biological characteristics of smolts with survival and travel time. Annual Report to BPA, 1987, Portland, Oregon. 57 p. U.S. Fish and Wildlife Service.

Rondorf, D. W., M. S. Dutchuk, A. S. Kolok, and M. L. Gross.

1985. Bioenergetics of juvenile salmon during the spring outmigration. Annual Report to BPA, 1983, Portland, Oregon. 78 p. U.S. Fish and Wildlife Service.

Sims, C. W., A. E. Giorgi, R. C. Johnsen, and D. A. Brege.

1984. Migrational characteristics of juvenile salmon and steelhead in the Columbia River Basin, 1983. Report to U.S. Army Corps of Engineers, Contract DACW57-83-F-0314, 47 p. Available from Northwest Fisheries Center, 2725 Montlake Blvd. E., Seattle, WA 98112-2097.

Swan, G. A., A. E. Giorgi, T. C. Coley, and W. T. Norman.

1987. Testing fish guiding efficiency of submersible traveling screens at Little Goose Dam; Is it affected by smoltification levels in yearling chinook salmon? Report to U.S. Army Corps of Engineers, Contract DACW68-84-H-0034, 58 p. + Appendixes. Available from Northwest Fisheries Center, 2725 Montlake Blvd. E., Seattle, WA 98112-2097.

Wagner, H. H.

1974. Photoperiod and temperature regulation of smolting in steelhead trout

(Salmo gairderi).. Can. J. Zool. 52:219-234.

Wedemeyer, G. A., R. L. Saunders, and W. C. Clarke.

1980. Environmental factors affecting smoltification and early marine survival of anadromous salmonids. Mar. Fish. Rev. 42:1-14.

Winans, G. A.

1984. Multivariate morphometric variability in Pacific salmon: technical demonstration. Can. J. Fish. Aquat. Sci. 41:1150-1159.

Winans, G. A., and R. S. Nishioka.

1987. A multivariate description of change in body shape of coho salmon (Oncorhvnchus kisutch) during smoltification. Aquaculture 66:235-245. 
Zaugg, W. S.

1981. Relationship between smolt indices and migration in controlled and natural environments, p. 173-183. In E. L. Brannon and E. 0. Salo (eds.), Salmon and Trout Migratory Behavior Symposium.

Zaugg, W. S.

1982. A simplified preparation for adenosine triphosphatase determination in gill tissue. Can. J. Fish. Aquat. Sci. 39:215-217.

Zaugg, W. S., E. F. Prentice, and F. W. Waknitz.

1985. Importance of river migration to the development of seawater tolerance in Columbia river anadromous salmonids. Aquaculture 51:33-47.

Zaugg, W. S., and H. H. Wagner.

1973. Gill ATPase activity related to parr-smolt transformation and migration in steelhead trout (Salmo gairdneri):influence of photoperiod and temperature. Comp. Biochem. Physiol. 45B:955-965. 
APPENDIXES 
FY88 Budget Summary

Dworshak Photoperiod Study

Personnel

Travel

$23,706.51$

Transportation

833.62

36.56

Rents, Communications

$1,430.58$

Contracts

Supplies

$1,944.21$

Equipment

$1,308.23$

support cost

0.0

Total

8.171.25

$37,430.96$ 
Appendix Table 1.--Mann-Whitney U-tests for gill $\mathrm{Na}^{+}-\mathrm{K}^{+}$ATPase data from spring chinook salmon from Dworshak photoperiod experiment. $\mathrm{T}=$ test; $\mathrm{C}=$ control. Units for $\mathrm{Na}^{+}-\mathrm{K}^{+}$ATPase are $\mu \mathrm{mol} \mathrm{Pi} \cdot \mathrm{mg} \mathrm{Prot}^{-1} \cdot \mathbf{h}^{-\mathbf{1}}$. Probabilities are two-tailed.

\begin{tabular}{|c|c|c|c|c|c|c|c|}
\hline $\begin{array}{l}\text { Sample } \\
\text { site }\end{array}$ & Date & $\begin{array}{c}\text { Test } \\
\text { condition }\end{array}$ & $\overline{\mathbf{x}}$ & Median & $\mathrm{n}$ & $\mathrm{U}$ & $\mathrm{P}$ \\
\hline \multirow{7}{*}{$\begin{array}{l}\text { Dworshak } \\
\text { National } \\
\text { Fish } \\
\text { Hatchery }\end{array}$} & $17 \mathrm{Dec}$ & $\begin{array}{l}\mathrm{T} \\
\mathrm{C}\end{array}$ & $\begin{array}{l}6.0 \\
7.0\end{array}$ & $\begin{array}{l}5.6 \\
7.4\end{array}$ & $\begin{array}{l}12 \\
12\end{array}$ & 113.0 & 0.0194 \\
\hline & 19 Jan & $\begin{array}{l}\mathrm{T} \\
\mathrm{C}\end{array}$ & $\begin{array}{l}6.7 \\
7.6\end{array}$ & $\begin{array}{l}6.7 \\
7.7\end{array}$ & $\begin{array}{l}12 \\
12\end{array}$ & 111.0 & 0.0262 \\
\hline & $1 \mathrm{Mar}$ & $\begin{array}{l}\mathrm{T} \\
\mathrm{C}\end{array}$ & $\begin{array}{l}9.6 \\
8.8\end{array}$ & $\begin{array}{l}9.0 \\
8.8\end{array}$ & $\begin{array}{l}12 \\
12\end{array}$ & 87.0 & 0.0405 \\
\hline & 7 Mar & $\begin{array}{l}\mathrm{T} \\
\mathrm{C}\end{array}$ & $\begin{array}{l}9.4 \\
9.3\end{array}$ & $\begin{array}{l}9.5 \\
9.6\end{array}$ & $\begin{array}{l}12 \\
12\end{array}$ & 72.0 & 0.9770 \\
\hline & 15 Mar & $\begin{array}{l}\mathrm{T} \\
\mathrm{C}\end{array}$ & $\begin{array}{l}12.0 \\
10.0\end{array}$ & $\begin{array}{l}12.1 \\
10.1\end{array}$ & $\begin{array}{l}12 \\
12\end{array}$ & 104.0 & 0.0690 \\
\hline & $22 \mathrm{Mar}$ & $\begin{array}{l}\mathrm{T} \\
\mathrm{C}\end{array}$ & $\begin{array}{l}14.0 \\
10.4\end{array}$ & $\begin{array}{l}13.4 \\
10.4\end{array}$ & $\begin{array}{l}12 \\
12\end{array}$ & 127.0 & 0.0017 \\
\hline & 29 Mar & $\begin{array}{l}\mathrm{T} \\
\mathrm{C}\end{array}$ & $\begin{array}{l}15.0 \\
13.6\end{array}$ & $\begin{array}{l}15.7 \\
13.4\end{array}$ & $\begin{array}{l}12 \\
11\end{array}$ & 87.5 & 0.1962 \\
\hline $\begin{array}{l}\text { Lower } \\
\text { Granite } \\
\text { Dam }\end{array}$ & $18 \mathrm{Apr}$ & $\begin{array}{l}\mathrm{T} \\
\mathrm{C}\end{array}$ & $\begin{array}{l}30.4 \\
24.8\end{array}$ & $\begin{array}{l}30.5 \\
24.4\end{array}$ & $\begin{array}{l}12 \\
12\end{array}$ & 117.5 & 0.0094 \\
\hline \multicolumn{2}{|c|}{ McNary Dam29 Apr } & $\begin{array}{l}\mathrm{T} \\
\mathrm{C}\end{array}$ & $\begin{array}{l}38.5 \\
38.7\end{array}$ & $\begin{array}{l}37.9 \\
38.2\end{array}$ & $\begin{array}{l}12 \\
12\end{array}$ & 74.0 & 0.9310 \\
\hline
\end{tabular}


Appendix Table 2.--Mann-Whitney U-tests for thyroxine $\left(\mathbf{T}_{\mathbf{4}}\right)$ data from spring chinook salmon from Dworshak photoperiod experiment. $\mathbf{T}=$ test; $\mathrm{C}=$ control. Units for $\mathrm{T}_{\mathbf{4}}$ are $\mathbf{n g m l}^{-1}$. Probabilities are two-tailed.

\begin{tabular}{|c|c|c|c|c|c|c|c|}
\hline $\begin{array}{l}\text { Sample } \\
\text { site }\end{array}$ & Date & $\begin{array}{c}\text { Test } \\
\text { condition }\end{array}$ & $\overline{\mathbf{x}}$ & Median & $\mathrm{n}$ & $\mathrm{U}$ & $\mathrm{P}$ \\
\hline \multirow{8}{*}{$\begin{array}{l}\text { Dworshak } \\
\text { National } \\
\text { Fish } \\
\text { Hatchery }\end{array}$} & 17 Dec & $\begin{array}{l}\mathrm{T} \\
\mathrm{C}\end{array}$ & $\begin{array}{l}5.4 \\
5.4\end{array}$ & $\begin{array}{l}5.4 \\
5.1\end{array}$ & $\begin{array}{l}12 \\
12\end{array}$ & 74.0 & 0.9310 \\
\hline & 19 Jan & $\begin{array}{l}\mathrm{T} \\
\mathrm{C}\end{array}$ & $\begin{array}{l}6.3 \\
5.7\end{array}$ & $\begin{array}{l}6.5 \\
6.0\end{array}$ & $\begin{array}{l}12 \\
12\end{array}$ & 85.0 & 0.4705 \\
\hline & 22 Feb & $\begin{array}{l}\mathrm{T} \\
\mathrm{C}\end{array}$ & $\begin{array}{l}8.0 \\
7.4\end{array}$ & $\begin{array}{l}8.5 \\
7.5\end{array}$ & $\begin{array}{l}12 \\
12\end{array}$ & 94.0 & 0.2145 \\
\hline & $1 \mathrm{Mar}$ & $\begin{array}{l}\mathrm{T} \\
\mathrm{C}\end{array}$ & $\begin{array}{l}6.7 \\
7.3\end{array}$ & $\begin{array}{l}7.0 \\
7.3\end{array}$ & $\begin{array}{l}12 \\
12\end{array}$ & 84.0 & 0.5067 \\
\hline & 7 Mar & $\begin{array}{l}\mathrm{T} \\
\mathrm{C}\end{array}$ & $\begin{array}{l}5.6 \\
5.6\end{array}$ & $\begin{array}{l}4.8 \\
4.6\end{array}$ & $\begin{array}{l}12 \\
12\end{array}$ & 75.0 & 0.8852 \\
\hline & 15 Mar & $\begin{array}{l}\mathrm{T} \\
\mathrm{C}\end{array}$ & $\begin{array}{l}7.0 \\
6.0\end{array}$ & $\begin{array}{l}5.2 \\
5.8\end{array}$ & $\begin{array}{l}11 \\
12\end{array}$ & 76.0 & 0.5588 \\
\hline & $22 \mathrm{Mar}$ & $\begin{array}{l}\mathrm{T} \\
\mathrm{C}\end{array}$ & $\begin{array}{l}5.2 \\
7.9\end{array}$ & $\begin{array}{l}4.9 \\
6.9\end{array}$ & $\begin{array}{l}12 \\
11\end{array}$ & 104.0 & 0.0210 \\
\hline & $29 \mathrm{Mar}$ & $\begin{array}{l}\mathrm{T} \\
\mathrm{C}\end{array}$ & $\begin{array}{l}3.5 \\
4.6\end{array}$ & $\begin{array}{l}3.4 \\
4.6\end{array}$ & $\begin{array}{l}12 \\
12\end{array}$ & 108.0 & 0.0404 \\
\hline $\begin{array}{l}\text { Lower } \\
\text { Granite } \\
\text { D a m }\end{array}$ & 18 Apr & $\begin{array}{l}\mathrm{T} \\
\mathrm{C}\end{array}$ & $\begin{array}{l}5.9 \\
8.0\end{array}$ & $\begin{array}{l}5.8 \\
7.3\end{array}$ & $\begin{array}{l}12 \\
12\end{array}$ & 112.0 & 0.0226 \\
\hline \multicolumn{2}{|c|}{ McNary Dam29 Apr } & $\begin{array}{l}\mathrm{T} \\
\mathrm{C}\end{array}$ & $\begin{array}{l}5.3 \\
6.1\end{array}$ & $\begin{array}{l}4.8 \\
6.8\end{array}$ & $\begin{array}{l}12 \\
12\end{array}$ & 78.0 & 0.7508 \\
\hline
\end{tabular}


Appendix Table 3.--Mann-Whitney U-tests for triiodothyronine $\left(\mathbf{T}_{3}\right)$ data from spring chinook salmon from Dworshak photoperiod experiment. $\mathrm{T}=$ test; $\mathrm{C}=$ control. Units for $\mathrm{T}_{3}$ are $\mathbf{n g m l}^{-\mathbf{1}}$. Probabilities are two-tailed.

\begin{tabular}{|c|c|c|c|c|c|c|c|}
\hline $\begin{array}{l}\text { Sample } \\
\text { site }\end{array}$ & Date & $\begin{array}{c}\text { Test } \\
\text { condition }\end{array}$ & $\overline{\mathrm{x}}$ & Median & $\mathrm{n}$ & $\mathrm{U}$ & $\mathrm{P}$ \\
\hline \multirow{8}{*}{$\begin{array}{l}\text { Dworshak } \\
\text { National } \\
\text { Fish } \\
\text { Hatchery }\end{array}$} & 17 Dec & $\begin{array}{l}\mathrm{T} \\
\mathrm{C}\end{array}$ & $\begin{array}{l}1.0 \\
1.2\end{array}$ & $\begin{array}{l}1.0 \\
1.2\end{array}$ & $\begin{array}{l}12 \\
11\end{array}$ & 82.0 & 0.3401 \\
\hline & 19 Jan & $\begin{array}{l}\mathrm{T} \\
\mathrm{C}\end{array}$ & $\begin{array}{l}1.9 \\
1.5\end{array}$ & $\begin{array}{l}2.2 \\
1.1\end{array}$ & $\begin{array}{l}11 \\
12\end{array}$ & 98.0 & 0.0525 \\
\hline & $22 \mathrm{Feb}$ & $\begin{array}{l}\mathrm{T} \\
\mathrm{C}\end{array}$ & $\begin{array}{l}2.9 \\
2.6\end{array}$ & $\begin{array}{l}2.7 \\
3.1\end{array}$ & $\begin{array}{l}11 \\
12\end{array}$ & 68.5 & 0.9020 \\
\hline & $1 \mathrm{Mar}$ & $\begin{array}{l}\mathrm{T} \\
\mathrm{C}\end{array}$ & $\begin{array}{l}2.9 \\
2.7\end{array}$ & $\begin{array}{l}2.6 \\
2.3\end{array}$ & $\begin{array}{l}10 \\
11\end{array}$ & 58.5 & 0.8327 \\
\hline & $7 \mathrm{Mar}$ & $\begin{array}{l}\mathrm{T} \\
\mathrm{C}\end{array}$ & $\begin{array}{l}2.4 \\
2.8\end{array}$ & $\begin{array}{l}1.9 \\
2.1\end{array}$ & $\begin{array}{r}10 \\
8\end{array}$ & 49.0 & 0.4501 \\
\hline & $15 \mathrm{Mar}$ & $\begin{array}{l}\mathrm{T} \\
\mathrm{C}\end{array}$ & $\begin{array}{l}2.6 \\
2.9\end{array}$ & $\begin{array}{l}2.6 \\
2.6\end{array}$ & $\begin{array}{l}11 \\
12\end{array}$ & 74.0 & 0.6444 \\
\hline & $22 \mathrm{Mar}$ & $\begin{array}{l}\mathrm{T} \\
\mathrm{C}\end{array}$ & $\begin{array}{l}1.4 \\
3.6\end{array}$ & $\begin{array}{l}1.0 \\
3.5\end{array}$ & $\begin{array}{l}10 \\
10\end{array}$ & 90.0 & 0.0028 \\
\hline & $29 \mathrm{Mar}$ & $\begin{array}{l}\mathrm{T} \\
\mathrm{C}\end{array}$ & $\begin{array}{l}0.6 \\
1.0\end{array}$ & $\begin{array}{l}0.4 \\
0.9\end{array}$ & $\begin{array}{l}11 \\
12\end{array}$ & 98.0 & 0.0525 \\
\hline $\begin{array}{l}\text { Lower } \\
\text { Granite } \\
\text { Dam }\end{array}$ & 18 Apr & $\begin{array}{l}\mathrm{T} \\
\mathrm{C}\end{array}$ & $\begin{array}{l}1.9 \\
2.1\end{array}$ & $\begin{array}{l}1.4 \\
2.0\end{array}$ & $\begin{array}{l}11 \\
12\end{array}$ & 82.0 & 0.3401 \\
\hline \multicolumn{2}{|c|}{ McNary Dam29 Apr } & $\begin{array}{l}\mathrm{T} \\
\mathrm{C}\end{array}$ & $\begin{array}{l}2.0 \\
2.7\end{array}$ & $\begin{array}{l}2.1 \\
2.6\end{array}$ & $\begin{array}{l}12 \\
11\end{array}$ & 89.0 & 0.1661 \\
\hline
\end{tabular}

